\title{
Assessment of Physical and Chemical Characteristics of Surface Water from River Niger, Illushi, Edo State, Nigeria
}

*OSEJI, M; UWAIFO, OP; OMOGBEME, MI

Department of Animal and Environmental Biology, Faculty of Life Science, University of Benin, P.M.B 1154, Benin City, Nigeria.

*Corresponding Author Email: Osejimacpherson@gmail.com

\begin{abstract}
The physical and chemical characteristics of River Niger, Illushi an important fishing site in Edo State which is currently impacted by human activities, was investigated between the month of April and November, 2017. Surface water samples were collected from three (3) sampling stations covering a total distance of $2600 \mathrm{metres}$ from upstream to downstream, and a total of seventeen (17) physical/chemical parameters were investigated. Findings from this study revealed that Air temperature had an average mean value of $27 \pm 0.72 \mathrm{mg} / \mathrm{L}$, Water temperature was $26.21 \pm 0.63 \mathrm{mg} / \mathrm{L}$, the river was generally acidic with the average $\mathrm{pH}$ of $6.27 \pm 0.18$, Turbidity was $107.28 \pm 30.9$, Conductivity was 57.08 \pm 8.29 , Total Dissolved Solid was 34.9 \pm 4.78 , Total Suspended Solid was $71.7 \pm 21.17 \mathrm{mg} / \mathrm{L}$, Alkalinity was $26.62 \pm 4.78 \mathrm{mg} / \mathrm{L}$, Chloride was $17.29 \pm 1.41 \mathrm{mg} / \mathrm{L}$, Hardness was $26.81 \pm 2.59 \mathrm{mg} / \mathrm{L}$, Phosphate was $2.20 \pm 0.09 \mathrm{mg} / \mathrm{L}$, Nitrate was $3.19 \pm 0.94 \mathrm{mg} / \mathrm{L}$, Sulphate was $25.81 \pm 10.78 \mathrm{mg} / \mathrm{L}$, Calcium was $8.69 \pm 1.74 \mathrm{mg} / \mathrm{L}$, Magnesium was $2.66 \pm 0.39 \mathrm{mg} / \mathrm{L}$, Dissolved Oxygen was $4.47 \pm 0.46 \mathrm{mg} / \mathrm{L}$ and Biochemical Oxygen Demand was $7.29 \pm 3.25 \mathrm{mg} / \mathrm{L}$. This study depicts that turbidity, dissolved oxygen, biochemical oxygen demand, air, and water temperature were higher than the recommended limit for drinkable water. It, therefore, stresses the need for compliance of environmental laws to prevent the river from further deterioration.
\end{abstract}

\section{DOI: $\underline{\text { https://dx.doi.org/10.4314/jasem.v23i1.29 }}$}

Copyright: Copyright (C) 2019 Oseji et al. This is an open access article distributed under the Creative Commons Attribution License (CCL), which permits unrestricted use, distribution, and reproduction in any medium, provided the original work is properly cited.

Dates: Received: 16 December 2018; Revised: 20 January 2019; Accepted 29 January 2019

KEYWORDS: Surface water, physicochemical parameters, River Niger, Illushi.

Water is one of the most essential compounds that enable the survival of living organisms on earth (Akpofure et al., 2007). As one of the most valuable resources to man and living organism, water is essential for the sustenance of life on earth and this is exemplified by its diversified uses which include washing, irrigation, cooking and drinking. Thus, water is life and its quality is an essential measure of the quality of life (Oboh and Agbala, 2017). The freshwater resources of Nigeria constitute about $12.4 \%$ of its total surface area (Dimowo, 2013). One of the most recent problems in developing countries like Nigeria is the shortage of clean water, particularly in rural communities that rely on rivers as their main source of domestic water supply. The deteriorating quality of water threatens sustainable living in these communities and it is, therefore, a reason for worry (Omoigberale et al., 2013). Sadly, rivers are been polluted by indiscriminate dumping of sewage, waste from industries, agricultural waste and other human activities, which in turn, affect the physical and chemical characteristics of these water bodies (Koshy and Nayar, 1999). River Niger, Illushi, an important fishing site in Edo State is currently impacted by human activities such as waste deposits, boating activities and agricultural runoffs from neighboring farmlands where the application of fertilizers is a common practice. Availability of clean and safe supply of drinking water is a requirement for sustainable growth and development (Asonye et al., 2007). Thus, the quality of water influences the wellbeing of any population that uses it. Hence, an examination of water for physical and chemical characteristics is essential for public health studies (Chinedu et al., 2011). The purpose of this study was to ascertain the level of anthropogenic influence on River Niger, Illushi, Edo State, Nigeria, by investigating the physical and chemical characteristics of its surface water, and thus, provide baseline data on the water quality.

\section{MATERIALS AND METHODS}

Study Area: This study was conducted in River Niger, Illushi, Edo State, Nigeria. Illushi lies between latitude $6^{\circ} \quad 40^{\prime} \quad 14.4^{\prime \prime}$ and $6^{0} \quad 40^{\prime} \quad 26.9^{\prime \prime}$ North, and Longitude $6^{\circ} 36^{\prime} 53.8^{\prime \prime}$ and $6^{0} 37^{\prime} 49.3^{\prime \prime}$ East. It is 16 $\mathrm{km}$ from Ubiaja along Ubiaja/ Illushi old road. The climate of Illushi is tropical with the dry season running from November to April and it is usually marked with a cool harmattan dusty haze from the North East winds while the wet season runs from May to October with a brief dry spell in August 
known as August break. The inhabitants of Illushi rely on River Niger as their domestic water supply, and the people are actively engaged in fishing and farming. Three sampling stations were selected for this study based on human activities in these areas. Station 1 is 1100 meters upstream of station 2 while station 3 is 1500 meters downstream of station 2 (Fig 1). The anthropogenic activities observed in station 1 include washing of clothes, bathing, washing of motorcycles and farming at the river bank. In station 2 , bathing, clothes washing, washing of harvested rice, and transportation of goods and humans with boats were the activities observed place during the period of sampling. In station 3 , transportation with boats, dumping of waste materials generated from the market and processing of local rice at the bank of the river were the human activities observed within this region during the sampling period.

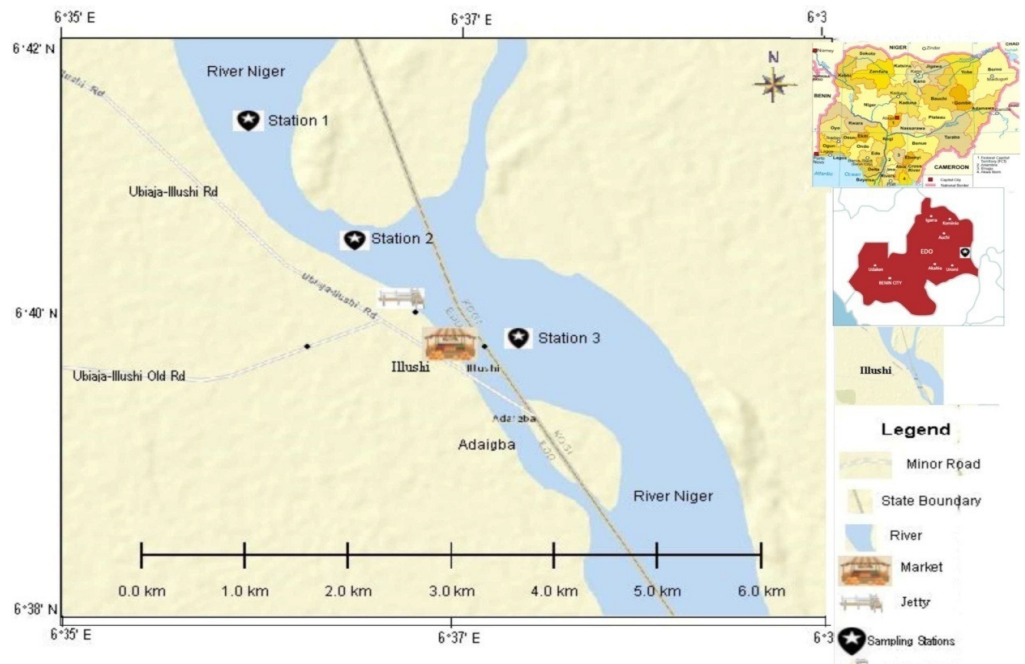

Fig. 1: Locations of sampled stations in the study area

Sample Collection: Samples were collected once a month for the period of eight months (April to November 2017). 1litre polyethylene bottles were used to collect water samples at $30 \mathrm{~cm}$ depth beneath the water surface according to the standard method (APHA, 2005). Prior to their use, the bottles were thoroughly washed and rinsed with deionized water. Dissolved oxygen (DO) and Biochemical oxygen demand (BOD) bottles $(250 \mathrm{ml})$ were used to collect water samples for dissolved oxygen and biological oxygen demand respectively. Precautions were taken to minimize the risk of contaminating the samples as they were being transported to the laboratory. The insitu measurement was carried out using a $\mathrm{pH}$ meter for $\mathrm{pH}$, TDS/Conductivity meter for electrical conductivity. Dissolved Oxygen and Biochemical Oxygen demand were estimated using Winkler's method. The BOD was carried out after 5 days of incubation at $20^{\circ} \mathrm{C}$. The other physical/chemical characteristics were examined using standard method (APHA, 1998).

Data Analysis: Data obtained from this study was statistically analyzed using the Statistical Package for Social Science (SPSS) version 16. Inter-station comparison was done using Analysis of variance (ANOVA) and Duncan Multiple Range (DMR) test was performed to determine the point of significant difference.

\section{RESULT AND DISCUSSION}

A summary of some physical and chemical characteristics of surface water from River Niger, Illushi, Edo State recorded from April to November, 2017 is presented in Table 1. Among the physical and chemical characteristics investigated, water temperature, conductivity, total dissolved solids, alkalinity and phosphate showed significant difference between the stations, while air temperature, $\mathrm{pH}$, turbidity, total suspended solids, chloride, hardness, nitrate, sulphate, calcium, DO, BOD and magnesium showed no significant difference $(p>0.05)$ between the stations. In general, air temperature ranged from 24 to $30{ }^{\circ} \mathrm{C}$, the mean air temperature recorded in stations 1 and 2 were slightly higher than the permitted limit, while that of station 3 was lower than the permissible limit of $27^{\circ} \mathrm{C}$ (WHO, 2004). Water temperature is an important factor for aquatic organisms to thrive, as it affects the rate of photosynthesis which aquatic organism needs to flourish. Water temperature ranged from 22 to $30^{\circ} \mathrm{C}$. Mean water temperature in stations 1 and 2 were lower than the permissible limit, while that of station 3 was slightly higher than the permissible limit. The 
high water temperature recorded in station 3 could be due to low vegetation cover and degree of exposure to solar heat (WHO, 2004). Oboh and Agbala (2017) recorded water temperature range of $29.5^{\circ} \mathrm{C}$ to $32.67^{\circ} \mathrm{C}$ in River Siluko.

Table 1: Summary of physical and chemical characteristics of surface water in River Niger from April 2017 to November 2017

\begin{tabular}{|c|c|c|c|c|c|c|c|c|c|c|}
\hline \multirow[b]{2}{*}{ Parameters } & \multicolumn{3}{|c|}{ Station 1} & \multicolumn{3}{|c|}{ Station 2} & \multicolumn{3}{|c|}{ Station 3} & \multirow{2}{*}{$\begin{array}{c}\text { P- } \\
\text { value }\end{array}$} \\
\hline & $\bar{X} \pm S D$ & Min & Max & $\bar{X} \pm S D$ & Min & Max & $\bar{X} \pm S D$ & Min & Max & \\
\hline \multicolumn{11}{|l|}{ Physical properties } \\
\hline Air Temperature (0C) & $27.38 \pm 0.59$ & 25 & 30 & $27.38 \pm 0.70$ & 24 & 29.5 & $26.25 \pm 0.85$ & 24 & 30 & $\mathrm{P}>0.05$ \\
\hline Water temperature (0C) & $25.25 \pm 0.37^{\mathbf{b}}$ & 24 & 27 & $25.69 \pm 0.88^{\mathbf{b}}$ & 22 & 29 & $27.69 \pm 0.63^{a}$ & 25 & 30 & $\mathrm{P}<0.05$ \\
\hline \multicolumn{11}{|l|}{ Chemical properties } \\
\hline $\mathrm{pH}$ & $6.38 \pm 0.17$ & 5.6 & 7.1 & $6.25 \pm 0.20$ & 5.2 & 7 & $6.2 \pm 0.18$ & 5.3 & 6.9 & $\mathrm{P}>0.05$ \\
\hline Turbidity (NTU) & $167.38 \pm 49.18$ & 35 & 433 & $85.35 \pm 29.87$ & 14 & 243 & $69.12 \pm 13.65$ & 28 & 140 & $\mathrm{P}>0.05$ \\
\hline Conductivity(us/cm) & $75.62 \pm 8.42^{\mathrm{a}}$ & 50 & 110 & $56.88 \pm 13.66^{\mathrm{a}}$ & 10 & 110 & $38.75 \pm 2.79^{\mathbf{b}}$ & 30 & 50 & $P<0.05$ \\
\hline TDS (mg/l) & $50.03 \pm 6.51^{\mathrm{a}}$ & 26.5 & 84.8 & $33.13 \pm 6.57^{\mathbf{b}}$ & 5.3 & 58.3 & $21.54 \pm 1.26^{\mathbf{b}}$ & 15.9 & 26.5 & $P<0.01$ \\
\hline TSS (mg/l) & $109.6 \pm 33.5$ & 22 & 288 & $57.19 \pm 19.58$ & 11 & 162 & $48.31 \pm 10.45$ & 21 & 106 & $\mathrm{P}>0.05$ \\
\hline Alkalinty (mg/l) & $42.12 \pm 3.86^{\mathrm{a}}$ & 20 & 58 & $17.75 \pm 5.40^{\mathbf{b}}$ & 6 & 54 & $20 \pm 5.074^{\mathbf{b}}$ & 4 & 44 & $P<0.01$ \\
\hline Chloride (mg/l) & $18.54 \pm 1.45$ & 14.1 & 24.7 & $17.22 \pm 1.40$ & 10.6 & 21.2 & $16.11 \pm 1.38$ & 10.6 & 21.2 & $\mathrm{P}>0.05$ \\
\hline Hardness $(\mathrm{CaCO} 3)(\mathrm{mg} / \mathrm{l})$ & $31.13 \pm 2.16$ & 24 & 42 & $23.94 \pm 2.78$ & 14 & 35 & $25.38 \pm 2.82$ & 16 & 38 & $\mathrm{P}>0.05$ \\
\hline Phosphate (mg/l) & $5.36 \pm 2.57^{\mathrm{a}}$ & 0.25 & 19.9 & $0.65 \pm 0.14^{b}$ & 0.16 & 1.41 & $0.61 \pm 0.07^{\mathbf{b}}$ & 0.29 & 0.88 & $P<0.05$ \\
\hline Nitrate $(\mathrm{mg} / \mathrm{l})$ & $4.94 \pm 1.89$ & 0.59 & 15.4 & $2.72 \pm 0.51$ & 0.88 & 5.22 & $1.92 \pm 0.40$ & 0.5 & 3.49 & $\mathrm{P}>0.05$ \\
\hline Sulphate $(\mathrm{mg} / \mathrm{l})$ & $34.31 \pm 8.72$ & 3 & 75 & $28.88 \pm 19.09$ & 5 & 162 & $14.25 \pm 4.53$ & 5 & 43 & $\mathrm{P}>0.05$ \\
\hline Calcuim (mg/l) & $11.84 \pm 2.97$ & 4.01 & 28.1 & $6.67 \pm 1.09$ & 2.41 & 12.02 & $7.56 \pm 1.15$ & 1.6 & 11.2 & $\mathrm{P}>0.05$ \\
\hline Magnesium (mg/l) & $3.33 \pm 0.66$ & 1 & 6.8 & $2.62 \pm 0.25$ & 1.5 & 3.4 & $2.04 \pm 0.25$ & 1 & 3.4 & $\mathrm{P}>0.05$ \\
\hline $\mathrm{DO}(\mathrm{mg} / \mathrm{l})$ & $3.99 \pm 0.35$ & 2.54 & 5.21 & $4.14 \pm 0.50$ & 2.4 & 6.1 & $5.30 \pm 0.52$ & 3.1 & 7.5 & $\mathrm{P}>0.05$ \\
\hline BOD (mg/l) & $8.05 \pm 1.52$ & 0.8 & 12.5 & $7.94 \pm 2.35$ & 1.2 & 21.3 & $5.89 \pm 1.42$ & 1.5 & 13.5 & $\mathrm{P}>0.05$ \\
\hline
\end{tabular}

The $\mathrm{pH}$ range from 5.2 to 7.1 across the stations and all the stations had mean $\mathrm{pH}$ below 7 , which indicates that the river is slightly acidic. The $\mathrm{pH}$ recorded in the three stations was lower than 6.6 to 8.5 recommended by WHO (2004). This study is in line with the study conducted by Andem et al. (2012) in Ona River. Turbidity is the determination of the muddiness or opaqueness of water and it is usually influenced by the total number of materials that are present in the water (Oboh and Agbala, 2017). Turbidity (14 to 433 NTU) was relatively high. The river was generally turbid as the turbidity values obtained in all the stations was higher than 5 NTU recommended limit (WHO (2004). This may have been influenced by phytoplankton in the open surface water (Chinedu et al., 2011). The conductivity range of 10 to $110 \mu \mathrm{s} / \mathrm{cm}$ was observed across the 3 stations. The higher conductivity recorded in station 1 is as a result of a nutrient load of surface runoffs from farms as well as washing of nutrient-rich groundwater and solution of salts from inundated agricultural land at the bank of this station. Conductivity in this study is however below the recommended limit of $500 \mu \mathrm{S} / \mathrm{cm}$ by WHO (2004). The mean conductivity value recorded in this present study is lower than $3752.74 \mu \mathrm{S} / \mathrm{cm}$ recorded in New Calabar River (Agbugui and Deekae, 2014). Total Dissolved Solids (TDS) ranged from 5.3 in station 2 to $84.8 \mathrm{mg} / \mathrm{l}$ in station 1 and the high TDS in Station 1 is due to anthropogenic activities such as washing of motorcycles, washing of clothes, bathing and runoffs which may have brought in particles from the surrounding land. The average TDS in the study area was, however, lower than the permissible limit (WHO, 2004). Solids in water are undesirable, for they degrade the quality of water, inhibit the photosynthetic process and reduce the utility of water (Ogbeibu and Anagbaso 2004). Total Suspended Solids (TSS) ranged from 11 to $288 \mathrm{mg} / \mathrm{l}$ across the stations. Waste disposal and surface run-offs are the sources of TSS. The result obtained from this present study is contrary to the study conducted by Ofonmbuk et al. (2014) in Ediene stream. The monthly alkalinity values ranged from 4.0 to 58.0 across the three stations. The high alkalinity in station 1 is as a result of runoffs which carries allochthonous organic materials from farmlands at the bank of this station into the river. The mean value of alkalinity recorded in this present study was higher than 13.75 $\mathrm{mg} / \mathrm{l}$ recorded by Francis (2011) in new Calabar river freshwater section but lower than the value recorded in Woji creek (Davies et al., 2008). The highest mean chloride $(18.54 \mathrm{mg} / \mathrm{l})$ was recorded in station 1 and the lowest mean chloride was recorded in station 3 . Chlorides occur naturally in rocks, other sources of includes fertilizers, sewage, and livestock wastes. The mean chloride recorded in all the stations was lower than WHO (2004) limit. A similar range was reported elsewhere in Edo state, Nigeria (Imoobe and Koye, 2011; Anyanwu, 2012). Hardness values ranged from $14.0 \mathrm{mg} / \mathrm{l}$ in station 2 to $42 \mathrm{mg} / \mathrm{l}$ in station 1. The hardness of water is the measure of the concentration of the multivalent cations, primarily it is equivalent to the calcium and magnesium concentrations of the water (Ababio, 2007). Epidemiological investigations have demonstrated a 
relationship between the hardness of drinking water and the risk of cardiovascular disease, growth retardation, reproductive failure (Sengupta, 2013). Hardness values recorded in all the stations were lower than the limit (WHO, 2004). Phosphate mean of $5.36 \mathrm{mg} / \mathrm{l}$ was recorded in station $1,0.65$ in station 2 and $0.61 \mathrm{mg} / \mathrm{l}$ in station 3 . The significantly higher phosphate recorded in station 1 may be as a result of the leaching of fertilizers residues from the farm at the bank of this station into the River by runoffs. Phosphate occurs naturally in rocks and is introduced into rivers as the water flows through the rocks. Excessive phosphate leads to a reduction in dissolved oxygen and an increase in eutrophication. The mean phosphate in the 3 stations was lower than the permissible limit (WHO, 2004). The result from this study is similar to the study conducted by Imaobong et al. (2012), but contrary to the study carried out by Osimen et al. (2015). The highest nitrate (4.94 mg/l) and sulphate $(34.31 \mathrm{mg} / \mathrm{l})$ mean were recorded in station 1 and the lowest means nitrate of $1.92 \mathrm{mg} / \mathrm{l}$ and sulphate of $14.25 \mathrm{mg} / \mathrm{l}$ were recorded in station 3 . The sources of nitrate are municipal waste, refuse dump, decaying plant and animal materials. The mean nitrate in the 3 stations was lower than the permissible limit (WHO, 2004). This present study is contrary to the study conducted by Iyiola (2014). Though there was no significant difference $(p>$ $0.05)$, the high sulphate in station 1 is as a result of agricultural activities such as the application of fertilizers which are transported by runoffs into the river (Essien-Ibok et al., 2010). The mean sulphate in the 3 stations was lower than the permissible limit (WHO, 2004). $0.01-26.60 \mathrm{mg} / \mathrm{l}$ was recorded by Okorafor et al. (2013). Calcium ranged from 1.60 in station 3 to $28.10 \mathrm{mg} / \mathrm{l}$ in station 1. Magnesium ranged from 1.0 to $6.8 \mathrm{mg} / \mathrm{l}$ across the stations. Calcium and Magnesium are among the most common minerals found in rocks and as such, they occur in waters and their salts are important contributors to the hardness of water. Calcium is required for bone and teeth formation. Magnesium mean value was lower than WHO, (2004) limit. The least mean for Dissolved Oxygen (3.99 $\mathrm{mg} / \mathrm{l})$ was observed in station 1 , while the highest mean (5.30 $\mathrm{mg} / \mathrm{l}$ ) was recorded in station 3. The low DO in station 1 could be due to the enormous amount of organic loads from the surrounding farmlands which require a high level of oxygen to break down. The mean DO in stations 1 and 2 were lower than the permissible limit while that of station 3 was higher than the limit (WHO, 2004). The DO range value recorded in this study is similar to $0.58-10.00 \mathrm{mg} / \mathrm{l}$ recorded by Ikongbeh et al. (2014) in Lake Akata. Biochemical Oxygen Demand (BOD) is a measure of the amount of oxygen required by micro-organism to break down organic matter in 1 liter of water (Clair et al., 2003). It is used to determine the pollution strength of wastewater. BOD which had the least mean $(5.89 \mathrm{mg} / \mathrm{l})$ in station 3 and the highest mean $(8.05 \mathrm{mg} / \mathrm{l})$ in station 1 . The mean BOD recorded in the 3 stations were higher than the permissible limit (WHO, 2004). The mean BOD values recorded in this present study is lower than $405.57 \mathrm{mg} / \mathrm{l}$ recorded in Ona River by Andem et al. (2012).

Conclusion: This study has shown that turbidity, dissolved oxygen, biochemical oxygen demand, air and water temperature of River Niger, Illushi, Edo State, Nigeria were higher than the recommended level for drinkable water, during the period of this study. This, therefore, stresses the need for compliance of environmental laws to prevent the river from further deterioration.

Acknowledgments: This study was undertaken with the support of the Department of Animal and Environmental Biology, University of Benin and the Benin Owenna River Basin Development Authority, University of Benin Joint Analytical Research Laboratory.

\section{REFERENCES}

Ababio, OY (2007). New school chemistry for senior secondary schools. Revised Edition. Pp 440 500.

Agbugui, MO; Deekae, SN (2014). Assessment of the physico-chemical parameters and Quality of water of the New Calabar-Bonny River, PortHarcourt, Nigeria. Cancer Bio. 4(1): 1 - 9.

Akpofure, RR; Ikhifa, GO; Okokoyo, PA (2007). Physical and chemical characteristics of some waters used for drinking and domestic purposes in the Niger Delta, Nigeria. J. Environ. Monit. Assess. 128: 475 - 482.

Andem, AB; Udofia, U; Okorafor, KA; Okete, JA; Ugwumba, AA (2012). A study on some physical and chemical characteristics of Ona River, Apata, Ibadan Southwest, Oyo State, Nigeria. Euro. J. Zoo Res. 1(2): 37 - 46.

Anyanwu, ED (2012). Physicochemical and some trace metal analysis of Ogba River, Benin City, Nigeria. Jordan J. Bio. Sci.. 5: 47 - 53.

APHA, (2005). Standard Method for the Examination of Water and Wastewater. American Public Health Association, American Water works Association and Water Pollution Control Federation, 21 $1^{\text {th }}$ Edition. Washington D.C McGraw - Hill, U.S.A. Pp 1252. 
Asonye, CC; Okolie, NP; Okenwa, EE; Iwuayanwu, UG (2007). Some physicochemical characteristics and heavy metal profiles of Nigeria Rivers. Acad. J. 6 (5): 17-24.

Chinedu, SN; Nwinyi, OC; Oluwadamisi, AY; Eze, VN (2011). Assessment of water quality in Canaanland, Ota, Southwest Nigeria. Agric. Biol. J. North Ameri. 2: 577 - 583.

Clair, NS; Perry, LM; Gene, FP (2003). Chemistry for environmental engineering and sciences $5^{\text {th }}$ Ed. New York. McGraw-Hill. Pp 63 - 71.

Davies, OA; Ugwamba, AA; Abolude, DS (2008). Physico-chemistry quality of Trans-Amadi (Woji) Creek, Portharcourt, Niger Delta Nigeria. J. Fish Intern. 3(3): 91 - 97.

Dimowo, BO (2013). Assessment of some physicochemical parameters of river Ogun (Abeokuta, Ogun State, Southwestern Nigeria) in comparison with National and international standards. Intern. J. Aqua. 3 (5): 79 - 84.

Essien -Ibok, MA; Akpan, AW; Udo, MT; Chude, LA; Umoh, IA; Asuquo, IE (2010). Seasonality in the physico-chemical characteristics of Mbo River, Akwa Ibom State, Nigeria. Nigerian J. Agric. Food. Environ. 6:60 - 72.

Francis, A; Ikpewe, I (2011). Physicochemistry of the New Calabar River Freshwater section and implications for Fish production. Proceedings of the $27^{\text {th }}$ Annual Conference and Biennial General Meeting of the Fisheries Society of Nigeria. Pp $386-391$.

Ikongbeh, OA; Tiamiyu, LO; Ayuba, VO; Okayi, RG (2014). Water Quality parameters of Lake Akata, Benue State, Nigeria. Proceedings of the $29^{\text {th }}$ Annual Conference of the Fisheries Society Nigeria. Pp 278 - 285.

Imaobong, EE; Louis, AC; Grace, CO; James, PU (2012). Studies of the physico-chemical characteristics and nutrients of a tropical rainforest river in South East Nigeria. Aquaculture, Aquarium, conservation and legislation. Intern. J. Bioflux. Soc. 5(3): $142-$ 162.

Imoobe, TO; Koye, PI (2011). Assessment of the impact of effluent from a soft drink processing factory on the physico-chemical parameters of Eruvbi stream, Benin City, Nigeria. Bayero J. Pure Appl. Sci. 4: 126 - 134.
Iyiola, AO (2014). Effects of Human activities on the productivity of Ogunpa River in Ibadan, Oyo State. Proceedings of the $29^{\text {th }}$ Annual Conference of the Fisheries Society of Nigeria. Pp 261 - 265.

Koshy, M; Nayar, TV (1999). Water quality aspect of River Pamba. Poll. Res. 8: 501 - 510.

Oboh, IP; Agbala, CS (2017). Water quality assessment of river Siluko, Edo State, Southern Nigeria using water quality index (WQI). Afri. J. Aquat. Sci. 33(1): 1 - 24.

Ofanmbuk, IO; Imaobong, EE; Emem, FE (2014). Physico-chemical parameters and macrobenthos of Ediene stream, Akwa Ibom State, Nigeria. Ameri. J. Biol. Life Sci. 2(5): 112 - 121.

Ogbeibu, AE; Anagboso, MU (2004). Baseline limnological investigation of the Utor River Esan Southeast, Edo State, Southern Nigeria: physical and chemical hydrology. Trop. Freshwater Biol. 12: $45-62$.

Okorafor, KA; Effanga, EO; Andem, AB; George, UU; Amos, DI (2013). Spatial variation in physical and chemical parameters and macroinvertebrates in the intertidal Regions of Calabar River, Nigeria. Greener J. Geo. Earth Sci. 1(2): 063-072.

Omoigberale, MO; Jonathan, OI; Joshua, II; Mercy, IA (2013). Seasonal variation in the bacteriological quality of Ebutte River, in Ehor community, Edo State, Nigeria. American J. Res. Comm. 1 (7): 59 - 69.

Osimen, EC; Elakhame, LA; Normamiukor, D (2015). Water quality and seasonal variations of physico-chemical parameters of Ojirami Reservoir, Edo State, Nigeria. Proceeding of $30^{\text {th }}$ FISON Annual Conference, November $22-27$, 2015. Pp 94-98.

Sengupta, P. (2013). Potential health impacts of hard water. Intern. J. Prev. Med. 4(8): 866 - 875.

WHO, (2004). Standard for Drinking Water Quality (Based on Guidelines for Drinking - Water Quality $3^{\text {rd }}$ Edition World Health Organization), Pp 1 - 4. 